\title{
The celebrity of Polish and French medicine - Józef Julian Franciszek Feliks Babiński (1857-1932)
}

\author{
Janusz H. Skalski', Marcin Gładki², Dariusz Pypłacz² \\ ${ }^{1}$ Department of Pediatric Cardiac Surgery, Polish-American Children's Hospital, Collegium Medicum Jagiellonian University, Kraków, Poland \\ 2 District Medical Center, Opole, Poland
}

\begin{abstract}
The paper presents a biography of Polish and French medical scientist, Józef Julian Franciszek Feliks Babiński (1857-1932), a son of Polish exiles to France after the unsuccessful insurrection against the Russian occupants. Born in Paris, Babiński considered Poland as his own home-country, being faithful and grateful citizen of France, his adopted country. He made his neurological department in Paris, a world famous medical centre at the turn of the 20th century. Currently for every student of medicine or physician practitioner, the name of Babiński immediately associates with the "toe phenomenon" (phénomène des orteils). The discovery of this "sign" (1896) is the crowning point of Babiński's work in semiology. He was a co-author of discoveries known under eponym names of syndromes: Babinski-Nageotte, Babinski-Fröhlich, Anton-Babinski and many others. Babiński emphasized his Polish origins, expressing his feeling towards two home countries (1922), "I am proud to have two countries - to one, I owe the knowledge, to the other, the country of my ancestors, the elements of my Polish soul...".
\end{abstract}

Key words: history of medicine, history of neurology, the Babinski sign, the toe phenomenon

A son of Polish exiles, whose father, an engineer and an insurrectionist against the Russian occupants, fearing repressions immigrated with his wife to France in 1848. His father instilled in Joseph a sense of dignity, patriotism towards Poland - his own home-country tormented by partitions - and gratefulness to France, his adopted country. Born in Paris on November 17, 1857, Babiński remained connected to Paris throughout his life; he attended a Polish secondary school in Batignolles and graduated at the Faculty of Medicine, University of Paris, in 1879. As an intern, he studied anatomopathology, physiology, histology and internal medicine. Edmé Félix Vulpian supervised his training in neurology. In 1985, he gained a doctor degree in medical sciences presenting a thesis on anatomico-clinical correlations in sclerosis multiplex (Étude anatomique et clinique sur la sclerose en plaques) $[1,2]$.

In 1885-1890, he was Jean-Martin Charcot's favorite assistant. In 1890, having passed a competitive examination, he became Chief Physician of Paris hospitals. Unfortunately, he failed to surmount the subsequent stage in his career, an ex-

Correspondence to:

prof. dr hab. med. Janusz Skalski, Klinika Kardiochirurgii Dziecięcej, Polsko-Amerykański Instytut Pediatrii, Collegium Medicum Uniwersytetu Jagiellońskiego, ul. Wielicka 265, 30-663 Kraków, Poland, phone: +48-12-658-20-11, fax: +48-12-658-10-81, e-mail: janusz_skalski@poczta.onet.pl

Received: May 29, 2007. Accepted in final form: May 31, 2007.

Conflict of interest: none declared.

Pol Arch Med Wewn. 2007; 117 (7): 327-330

Copyright by Medycyna Praktyczna, Kraków 2007 amination opening a path to associate and full professorship [3]. Intrigues in the Paris scientific society and the envy of competitors headed by Charcot prevented Babiński from pursuing a career within academic medicine. Paradoxically, this failure paved the road to future discoveries, since he achieved a perfect possibility, unheard of in a university setting, for becoming immersed in clinical observations and research [4]. He joined the Academy of Medicine only in 1914. In 1893, he was nominated Physician-in-Chief in a ward in the Hôpitaux de la Pitié, where he worked until retirement in 1922. His 100-bed ward was predominated by internal disease patients; these were entrusted to the care of interns, while Babiński was mostly involved with neurology. Since he took no university chair, he gave solely courses and private lectures. His talks combined with case consultations were extremely popular.

Babiński had a habit of pursuing a single problem, until he found a final solution. If he saw a new sign or symptom, he stayed shut away with the patient and spent hours examining him. He would become taciturn and introvert. Only when sure of his discoveries, would he share his results. He rarely spoke during the meetings of the Paris Neurological Society, but if he deemed his input necessary, his arguments were irrefutable, iron logic-based, of immense scientific significance, so the audience was enraptured.

The discovery of the "toe phenomenon" (phénomène des orteils) is the crowning point of Babiński's work in semiotics. 


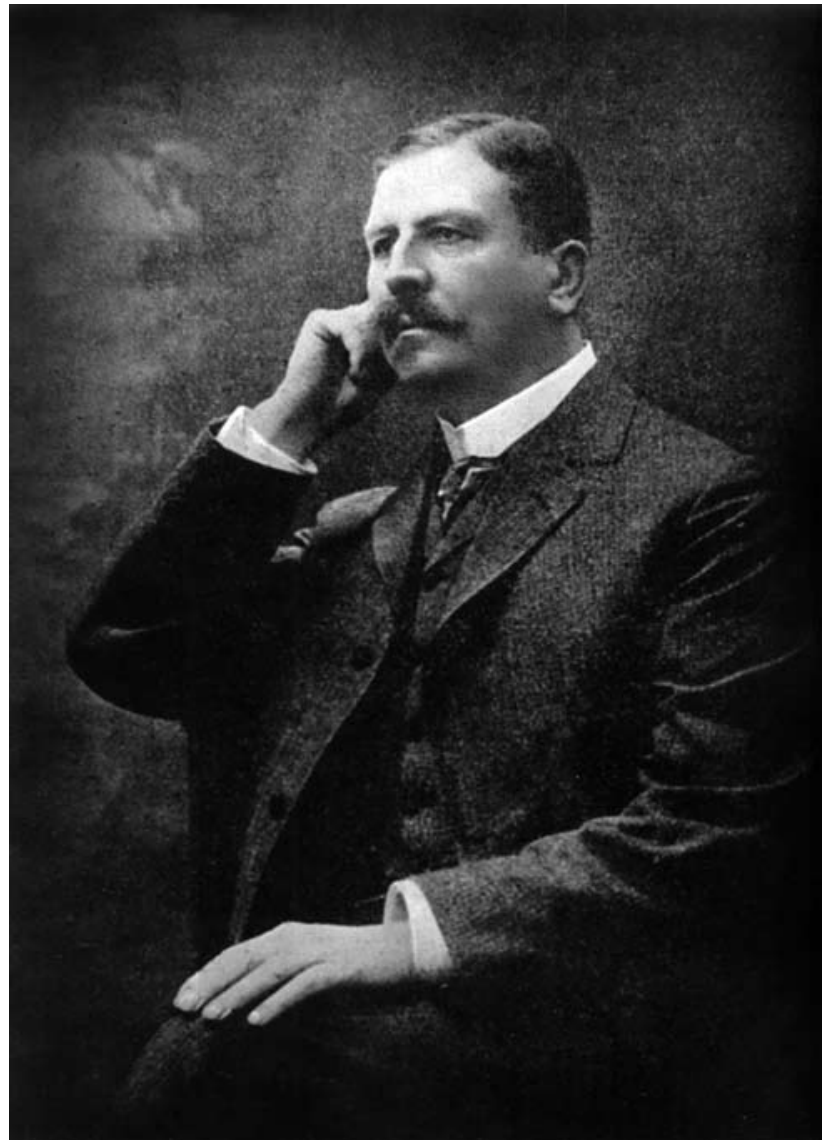

Fig. 1. Babiński in his forties. By courtesy of the Chair of History of Medicine, Collegium Medicum, Jagiellonian University

February 22, 1896, when the Paris Biological Society received the communication $O n$ the plantar reflex in some organic diseases of the nervous system became a historical date in neurology [5,6]. Typically of Babiński, ever economical with words; the report was only 28 lines long.

He supplemented the semiology of the reflex in 1903, describing toe abduction (the fan sign, signe d'éventail) $[7,8]$. He regarded it very important, stressing that in pyramidal tract damage, apart from great toe extension, the patient manifests also flexion and abduction of the other toes.

A superb clinician, Babiński understood that knowing neurological signs in normal and pathological situations is fundamentally important in neurology. His early papers focused on reflexes and establishing which were physiologically fixed and which developed in pathological states. He demonstrated that deep reflexes are fixed, but their hyperactivity, hypoactivity, absence or asymmetry indicate a pathology, and proved that conjunctival, corneal and gag reflexes may be absent in healthy subjects, but their asymmetry indicates an organic disease background. His famous lecture On tendon and periosteal reflexes precisely defined the role of reflexivity studies $[9,10]$.

Babiński developed the semiology of organic hemiplegia and transverse spinal cord lesions, described the majority of

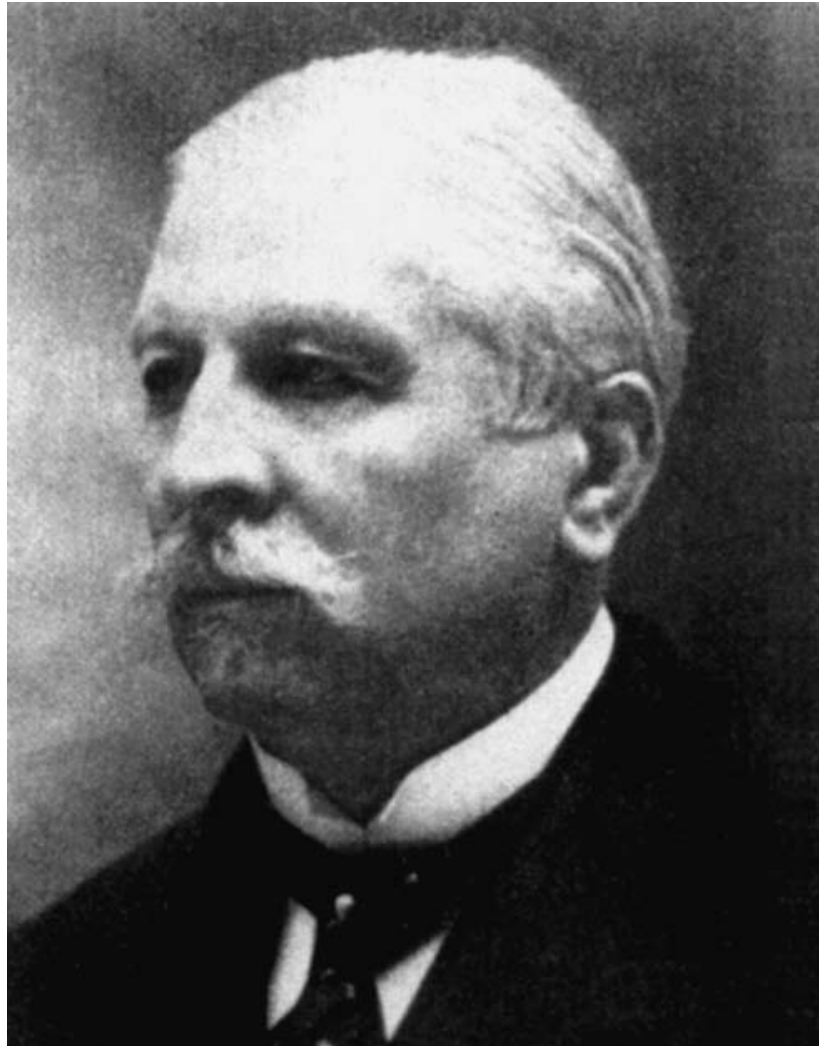

Fig. 2. Babiński in his sixties. By courtesy of the Chair of History of Medicine, Collegium Medicum, Jagiellonian University

pyramidal signs and demonstrated increased tendon and periosteal reflexes accompanied by the so-called clonus verus and toe sign as constant signs appearing in late-stage hemiplegias. He distinguished two types of transverse spinal cord paralysis: with tendon contraction or excessive tendon stretching; demonstrating defense reflexes in pyramidal tract damage and their independence of intensified tendon reflexes. Babiński's knowledge of defense reflexes allowed for determination of the spinal cord tumor margin.

Recognizing the diagnostic value of clinical characteristics of nervous system-affecting syphilis is among Babiński's major successes. In 1899, he was the first to claim that an absent pupil reaction to light was pathognomic; together with $\mathrm{Au}$ gustin Charpentier (1901), he showed the importance of the Argyll-Robertson pupil sign, equaling it in significance with the Hutchinson's triad or Fournier's pleiade [11].

In 1900, one year before Alfred Fröhlich [12], Babiński described adiposogenital dystrophy in pituitary tumors. Today, this syndrome is named after Babiński and Fröhlich.

Babiński concentrated on cerebellar symptomatology in 1899-1913; providing the foundation for diagnostic management of cerebellar diseases. The chief paper of that period seems to be a lecture On cerebellar signs and their diagnostic importance, presented at the International Medical Congress in London and published by Babiński and his student, August 

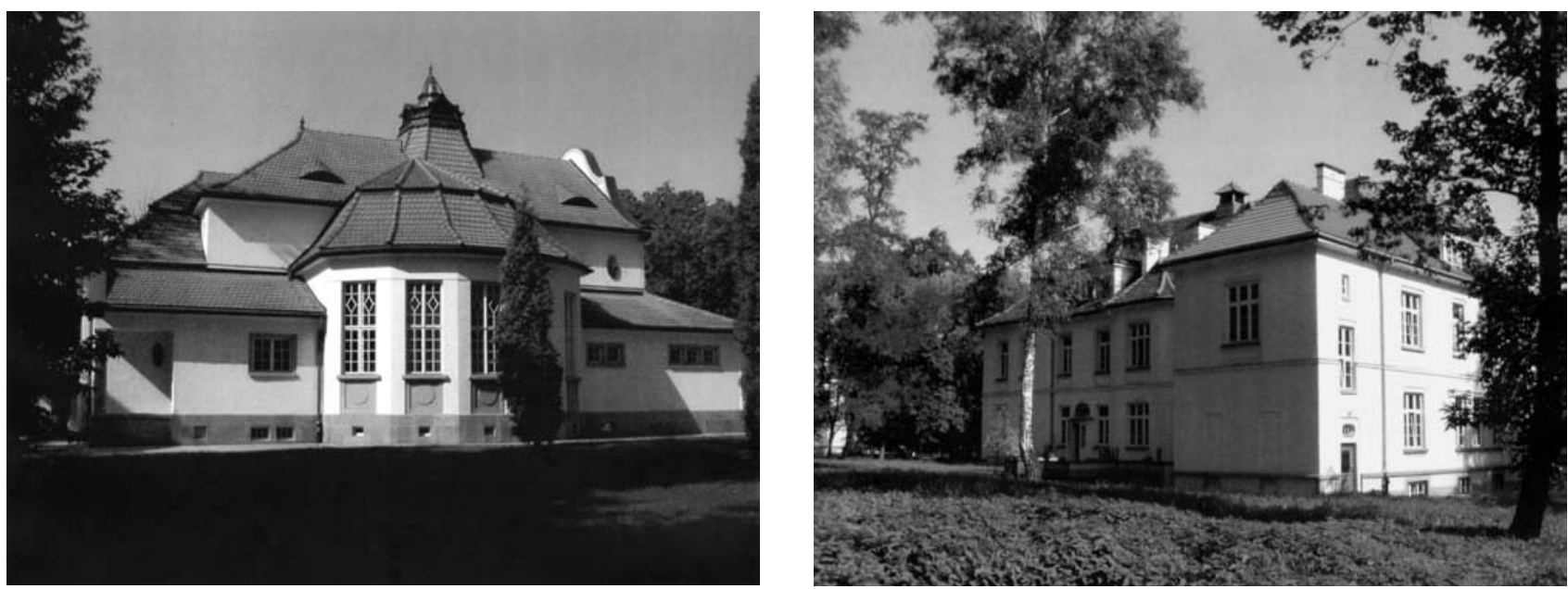

Fig. 3. Babinski Memorial Hospital in Kobierzyn (near Krakow). Two recently renovated buildings of 18 hospital facilities originating from 1918. By courtesy of the Management of Hospital

Tournay, in Neurologia Polska in 1914. Here Babiński described the signs he observed - hypermetria, asynergia, adiadochokinesis, intention tremor and catalepsy - later regarded as classic. Labyrinth testing by means of galvanic current introduced by Babiński (1901) allowed for diagnosing unilateral damage (mostly unilateral hearing defects). He described clinical features helpful in differentiating between cerebellar vs. peripheral and spinal ataxia. He believed a disturbed regulation in agonist and synergist innervation was a pathomechanism underlying cerebellar disturbances $[1,11]$.

Together with Jean Nageotte, Babiński distinguished a syndrome characteristic of vascular foci in the medulla oblongata (1902), presenting his observations in 1905-1906. This syndrome named after Babiński and Nageotte, today is recognized as a variant of lateral medullary syndrome; it develops when the posterior inferior cerebellar artery is occluded [13].

Babiński contributed to the discovery of a syndrome where a blind person negates his blindness (the Anton-Babiński syndrome; denial visual hallucination syndrome). Gabriel Anton described the phenomenon in 1899; Babiński introduced the term „anosognosia” (1914) in hemiplegic patients, who, unaware of their condition, demonstrated somatognosia and anosodiaphoria [11].

Babiński studied the nature of hysteria, which he regarded an effect of suggestive influence, termed "pitiatism" and believed treatable by persuasion. He also investigated the socalled physiopathological disturbances of a reflexive nature, usually trauma-evoked, publishing these observations together with Jules Froment (1917) in their book Hystérie-Pithiatisme et troubles nerveux d'ordre rérflexe [14].

Babiński was the first in France and among the first worldwide to understand and advocate surgical treatment of brain and spinal tumors, thus contributing to neurosurgery development. A break-through was a successful removal of a spinal tumor, preceded by a precise establishment of its localization by
Babiński (1911) [15]. He introduced X-ray irradiation in spinal compression (1906), developed the symptomatology of organic hemiplegia and transverse spinal cord lesions, cerebellar diseases, etc. He authored 288 papers. The University of Warsaw offered him the Chair of Neurology when it was established in 1925, but Babiński, a retiree, declined. He was elected honorary professor of the Vilnius University and honorary member of numerous scientific societies, including three in Poland. In 1899, he co-founded the French Société de Neurologie. In 1907, he became its president. Having retired - a great shock in itself - he continued consulting patients until 1931, when his brother Henry, a culinary master, died. Joseph was very close to Henry and they lived together for a long time. Henry's demise brought a breakdown. As his father's before, Babiński's last years were plagued by parkinsonism [1]. He died on October 29, 1932.

Babiński repeatedly emphasized his Polish origins. At the meeting with professors and physicians in Vilnius in 1922, he toasted his two home countries: "I am proud to have two countries - to one, I owe the knowledge, to the other, the country of my ancestors, the elements of my Polish soul. These two feelings have combined in me forming a unity...".

In his eulogy, Tournay thus spoke about this phenomenal scientist: "Il était beau, Il fut bon, Il restait vrai" [11] (He was beautiful. He was good. He remained true.).

\section{REFERENCES}

1. van Gijn J. The Babinski sign - a century. Utrecht, Universiteit Utrecht, 1996: 17-38.

2. Babinski J. Étude anatomique et clinique sur la sclérose en plaques. Paris, G Masson, 1885.

3. Vaquez H. Joseph Babinski (1857-1932). Bulletin de I'Académie de Médecine. 1932; 108: 1264-1273.

4. Iragui VJ. The Charcot-Bouchard controversy. Arch Neurol. 1986; 43: 290-295.

5. Babinski J. Sur le réflexe cutané plantaire dans certaines affections du système nerveux central. Comptes rendus des Séances et Mémoires de la Société de Biologie. 1896: 207-208

6. Babinski J. Du phénomène des orteils et de sa valeur semiologique. Semaine Médicale. 1898; 18: 321-322. 


\section{HISTORY OF INTERNAL MEDICINE IN POLAND}

7. Babinski J. De l'abduction des orteils. Revue Neurologique. 1903; 11: 728-729.

8. Babinski J. De l'abduction des orteils (signe de d'éventail). Revue Neurologique. 1903; 11: 1205-1206

9. Cohn R. The Babinski sign extinction during bilateral simultaneous cutaneous stimulation. J Neurophysiol. 1948; 11: 193-197.

10. Nathan PW. Effects on movement of surgical incisions into the human spinal cord. Brain. 1994; 117: 337-346.

11. Herman EJ. Historia neurologii polskiej. Wrocław, Zakład Ossolińskich, 1975; 97 147-155.

12. Babinski JF. Tumeur du corps pituitaire sans acromégalie et avec arrêt de développement des organes génitaux. Revue Neurologique. 1900; 8: 531-535.

13. Babinski JJFF, Nageotte J. Hémiasynergie, latéropulsion et myosis bulbaires avec hémianesthésie et hémiplégie croisées. Nouvelle iconographie de la Salpêtrière. Paris, G Masson, 1902.

14. Babinski JF, Froment J. Hystérie-pithiatisme et troubles nerveux d'ordre réflexe en neurologie de guerre. Paris, G Masson, 1917.

15. Lanzino G, di Pierro CG, Laws ER. One century after the description of the "sign": Joseph Babinski and his contribution to neurosurgery. Neurosurg. 1997; 40: 822 828. 